\title{
THE ROLE OF SELECTED BIOPHYSICAL FACTORS IN LONG- TERM LAND-USE CHANGE OF CULTURAL LANDSCAPE
}

\author{
OPRŠAL, Z. $^{1^{*}}-$ KLADIVO, ${ }^{2}{ }^{2}-$ MACHAR, I. $^{1}$ \\ ${ }^{1}$ Department of Development Studies, Faculty of Science, Palacký University \\ 17. listopadu 12, Olomouc 771 46, Czech Republic \\ ${ }^{2}$ Department of Geography, Faculty of Economics, University of West Bohemia \\ Husova 11, Plzen̆ 306 14, Czech Republic \\ *Corresponding author \\ e-mail: zdenek.oprsal@upol.cz \\ (Received $18^{\text {th }}$ Apr 2015; accepted $15^{\text {th }}$ Jan 2016)
}

\begin{abstract}
The paper addresses the importance of biophysical factors in land-use change over a period of time of more than 150 years beginning in the middle of the nineteenth century. Biophysical factors define the environmental capacity of a territory and can be viewed as a predisposition for changes in land use. The article investigates the impact of selected biophysical factors on land-use changes in the Trkmanka Watershed in the southeast part of the Czech Republic. The results of a canonical correspondence analysis demonstrated a relationship between selected variables and land-use changes. The most significant variables were slope grade, elevation and soil fertility, while aspect was of limited importance. Extensification processes are conditioned on less favourable environmental circumstances, especially steeper slope grade, higher elevation, less fertile soil and a north-facing slope. Intensive land use is associated with a lower slope grade and elevation, more fertile soils and a more favourable southern exposure. Although the results of the statistical analyses confirmed the importance of environmental factors, they explain only some of the overall land-use changes. It is clear that socioeconomic factors are the main forces influencing the character of land use.
\end{abstract}

Keywords: land-use change, biophysical factors, canonical correspondence analysis, Trkmanka Watershed, Czech Republic

\section{Introduction}

Land-use changes are tied to changes in the ecosystem services of the agricultural landscape, which have a direct impact on man's well-being (Duraiappah and Naeem, 2005; Vitousek et al., 1997). In addition to food production, these services also include soil erosion prevention measures (Feng et al., 2010; Zorn and Komac, 2009), protection of biodiversity (Pereira et al., 2010), climate change mitigation (Stone, 2009) and the cultural and aesthetic quality of the landscape (Xu et al., 2005). The study of changes in the development of the agricultural landscape and an understanding of the drivers of these changes serve as a basic guideline for anticipating the trajectory of future development (Veldkamp and Lambin, 2001) and assessing the influence of land related policies (Vliet et al., 2015). Better understanding of the interactions between land cover, land use and function may enhance our ability to properly model land changes (Verburg et al., 2009). This knowledge is important for establishing sustainable land management and for protecting basic land-use functions (Turner II, 1997) and related ecosystem services. Avoiding simplifications regarding the causes of land-cover land-use changes is a substantial prerequisite for sound and sustainable environment-development policies (Lambin et al., 2001). 
Land-use change and its drivers are usually investigated in local studies that often capture the period of the economic and/or social transition of society in recent decades. In this context, Vliet et al. (2015) identified three main contemporary processes impacting land-use change: the globalization of agricultural markets, the transition from a rural to an urban society and the shift to post-socialism in central and eastern Europe. Land-use change in the period of the adoption of a market-oriented economy after the era of socialism and the implementation of European Union policies during and after EU accession in postsocialist countries is a typical example of a relatively short-term transition with a more distinct dynamic attracting the interest of researchers. Articles on this regional research have recently been published from Slovakia (Pazúr et al., 2014; Lieskovský et al., 2014a), Albania (Müller et al., 2013), Ukraine (Baumann et al., 2011), Hungary (Szillasi et al., 2010) and the European part of Russia (Prishchepov et al., 2013). A common feature of these studies is the investigation of driving forces against the background of the extensification of the agricultural landscape.

The drivers of land changes can be divided into those of a biophysical and a socioeconomic nature (Mitsuda and Ito, 2011). Underlying drivers conditioned by people can be further divided into economic and technological factors, demographic factors, institutional factors and cultural factors (Geist and McConell, 2010). Verburg et al. (2004) presents a slightly different classification of land change determinants, which can be biophysical, economic, social, interactive, neighbourhood, and/or political nature. Finally, according to the Food and Agriculture Organization of the United Nations (FAO), the various reasons for agricultural land abandonment can be grouped in the following categories: natural constraints, land degradation, socio-economic factors, demographic structure and the institutional framework. The mentioned sources list various categories of human-related factors, all of which agree on the separate role of biophysical/natural constraints. It is not unusual for the study of land-use change to be focused on humanrelated factors (Łowicki, 2008; Song et al., 2013; Hietel et al., 2007; Krausmann et al., 2003) or, in contrast, environmental biophysical factors (Fu et al., 2006; Opršal et al., 2013). Recent studies that include selected socioeconomic and biophysical factors (Serra et al., 2008; Müller et al., 2009; Prishchepov et al., 2013; Pazúr et al., 2014) have two common traits. First of all, they are almost always extensive regional studies (involving an entire country or several regions) in which socioeconomic factors (e.g. the demographic structure of the population, migration, distance from regional economic centres) can be meaningfully modelled. Secondly, the studies are short-term in nature and are usually focused on changes occurring over the past several decades.

The research of drivers is common in geographically explicit historical studies of larger territories covering a time period of one-hundred years and more (Bičík et al., 2001; Cousins, 2001; Petit and Lambin, 2002). This situation can be explained in several ways, the most important being the apparent lack or absence of sufficiently accurate maps from historical time periods and the difficulty of converting them to digital form. For this reason, studies of historical land-use change often focus on smaller territories, typically municipalities (Kanianska et al., 2014; Druga and Falt'an, 2014). Another selection factor is the aforementioned preference for periods of major change, especially the period following the Second World War with a higher land-use change dynamic (Antrop, 2005). The third bias in case study selection has a geographical rather than a temporal nature - cases are more than can be expected by chance in areas which are considered hotspots for change (Vliet et al., 2015). These hotspots are usually located in marginal areas (Verburg and Overmars, 2009) typically in mountains (Schneeberger et al., 2007; Kuemmerle et al., 2009; 
Li et al., 2009; Alvarez Martinez et al., 2011) and/or dry-land areas (Lasanta and VicenteSerrano, 2012; Zhang et al., 2004; Li et al., 2007). Although it is understandable that scientists are primarily interested in change and not necessarily in regions that maintain the status quo (Vliet et al., 2015), such a selection might not be representative of all agriculture land in a respective region or country. Finally, Gerard et al. (2006) pointed to the fact that the degree of thematic detail and level of spatial detail of the land cover measured may determine the type, amount and rate of change detected and therefore to a certain extent determine the reliability of the results.

The aim of this article is to identify selected physical conditions and constraints that influence long-term land-use changes. The study of socioeconomic factors is tied to timelimited studies that often capture a period of the economic and/or social transition of society. However, socioeconomic factors in particular are highly variable and time-specific, and therefore their explanatory potential loses reliability in longitudinal studies (with the exception of certain demographic factors, especially out-migration). In contrast, natural conditions are relatively constant and hence their relevance is also retained in studies of long-term land-use development exceeding a timeframe of 100 years. The study is based on the reconstruction of the landscape in the middle of the nineteenth century using data from the Second Military Mapping Survey from 1836-1842. This time layer is compared to current land use, and the study thus captures a period of more than 150 years.

\section{Materials and Methods}

\section{Study area}

The Trkmanka Watershed is located in the southeast part of the Czech Republic (Figure 1). The Trkmanka Watershed represents a diversified area from the perspective of natural conditions and topography (Figure 2), and can be regarded as a representative type of agricultural landscape in the southeast part of the Czech Republic. The land slopes from the northeast to the southwest, and its total area is $380 \mathrm{~km}^{2}$. The watershed is an old settlement region characterised by a warm climate and fertile loessic soils. Long-term annual average precipitation in the entire territory is around $500 \mathrm{~mm}$ (Demek and Novák, 1992). The lowest southwest part of the watershed is characterised by flat alluvial relief, whereas the middle and northwest part is hilly (Demek and Mackovčin, 2006). The highest point in the region is at an elevation of $437.4 \mathrm{~m}$ above sea level, while the lowest point is the confluence of the Trkmanka and Dyje rivers at $158 \mathrm{~m}$ above sea level.

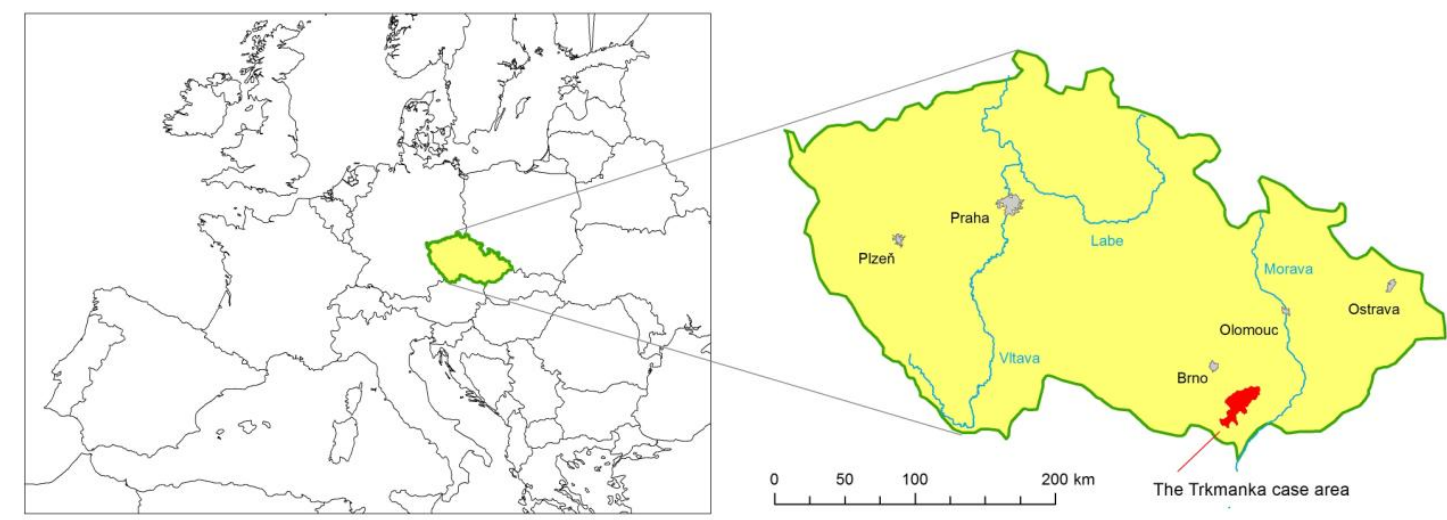

Figure 1. Location of the Trkmanka Watershed in Europe and the Czech Republic 


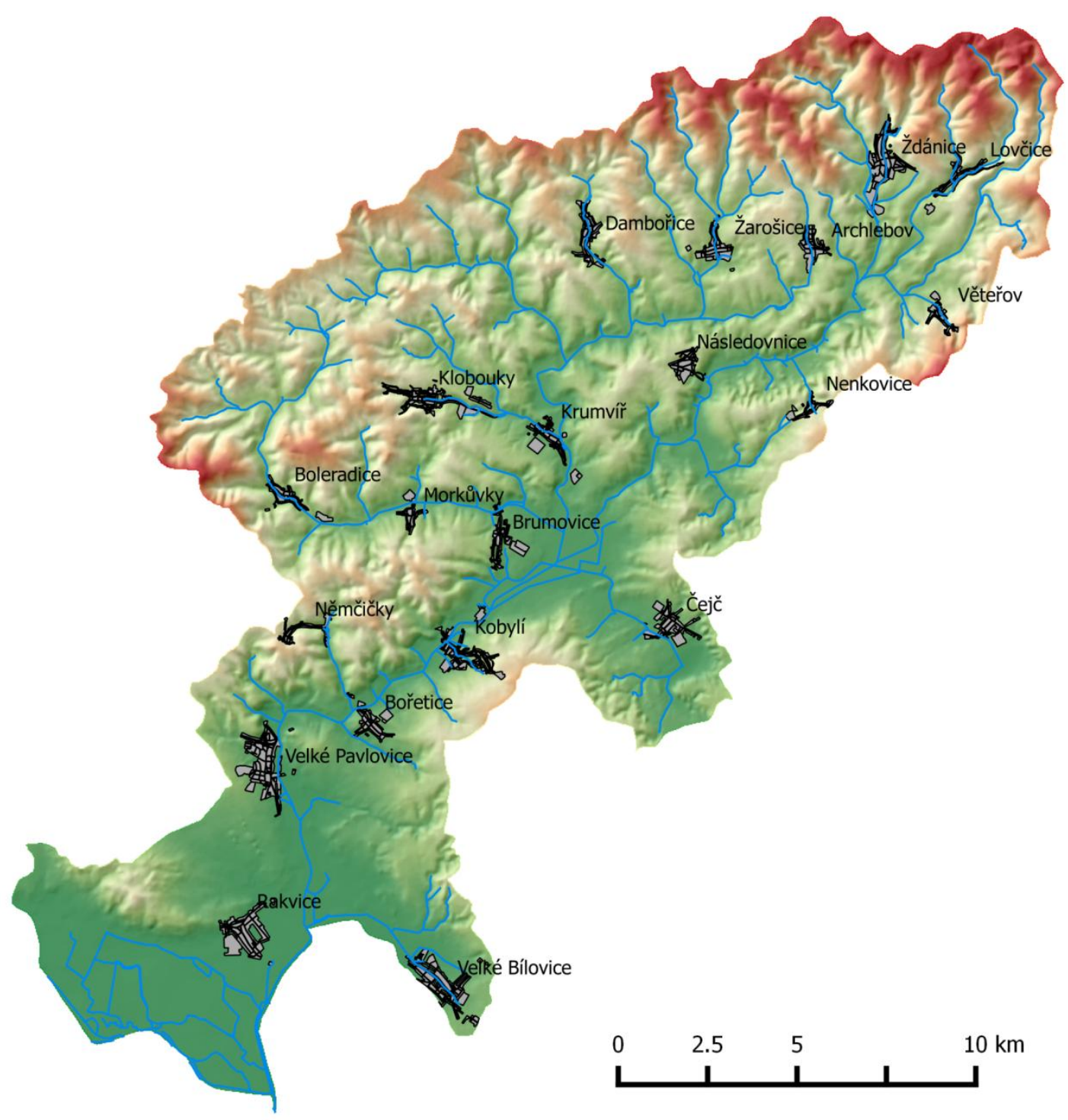

Figure 2. The study area of the Trkmanka Watershed, marking the current watercourses and settlements

Agricultural land was and continues to be a significant landscape element in a large part of the watershed (Kiliánová et al., 2009). The greatest land-use changes occurred after the middle of the nineteenth century in connection with innovation in the forms of agricultural production. The loss of grazing land in favour of arable land was connected with imports of cheap Australian wool, growth in stable cattle operations and later also the mechanisation of agricultural production. The intensification of agricultural production was also responsible for the demise of many natural and artificial bodies of water, of which only a fraction remain today. Among the unique wetlands that no longer exist were the Čejč and Kobylí salt lakes, which were drained during the nineteenth century (Kiliánová et al., 2009).

The forced collectivisation and intensification of agricultural production in the second half of the twentieth century represents another significant intervention in the 
structure of the landscape. Collectivisation was accompanied by the consolidation of land parcels and led to both a reduction in landscape diversity but also to the disruption of the traditional ties between owners and farm land (Bičík et al., 2001). The current form of the agricultural landscape is the result of long-term development reflecting changes in society, the economy, institutions and available technologies (Geist and McConell, 2010). In our article we work under the assumption that in addition to these time-variable socioeconomic factors, the current appearance of the land was also influenced by environmental and biophysical conditions that can be regarded as constant over the chosen time span of 150 years.

\section{Identification of historical and contemporary land use}

As the goal of the study is to assess the importance of biophysical factors in longterm land-use change, the first half of the nineteenth century was chosen as the baseline. This historical land use is compared to the current state of the land in 2008 (Figure 3). Historical land use was reconstructed using maps from the Second Military Mapping Survey (Franziszeische Landesaufnahme) conducted in Moravia (at the time part of the Czech lands within the Austro-Hungarian Empire) in 1836-1840. The survey has its foundation in the mapping for the Stable Cadastre established by the Land Tax Act (Grundsteuerpatent) from 1817 (Lisec and Navratil, 2013). The graphic topographic basis was the reduced content of the cadastral maps in a scale of 1:2 880. Topographic data of military importance (areas) were shown in eleven colours; terrain configuration was represented using Lehmann hachure. Elevation was given only at trigonometric points (Boguszak and Šlitr, 1962), the basic unit was the 'Vienna fathom' (Wiener Klafter) (Timár and Molnár, 2013). Six map sections (georeferenced and digitised) from the Second Military Mapping Survey were used for the analysis of the watershed. The digitisation and interpretation of orthophotos from 2004-2006 were used to determine current land use. Basic information on the area was refined and updated by supplementary field survey in 2008 (Kiliánová et al., 2009). All created vector data are in the ESRI shapefile format in the S-JTSK coordinate system.
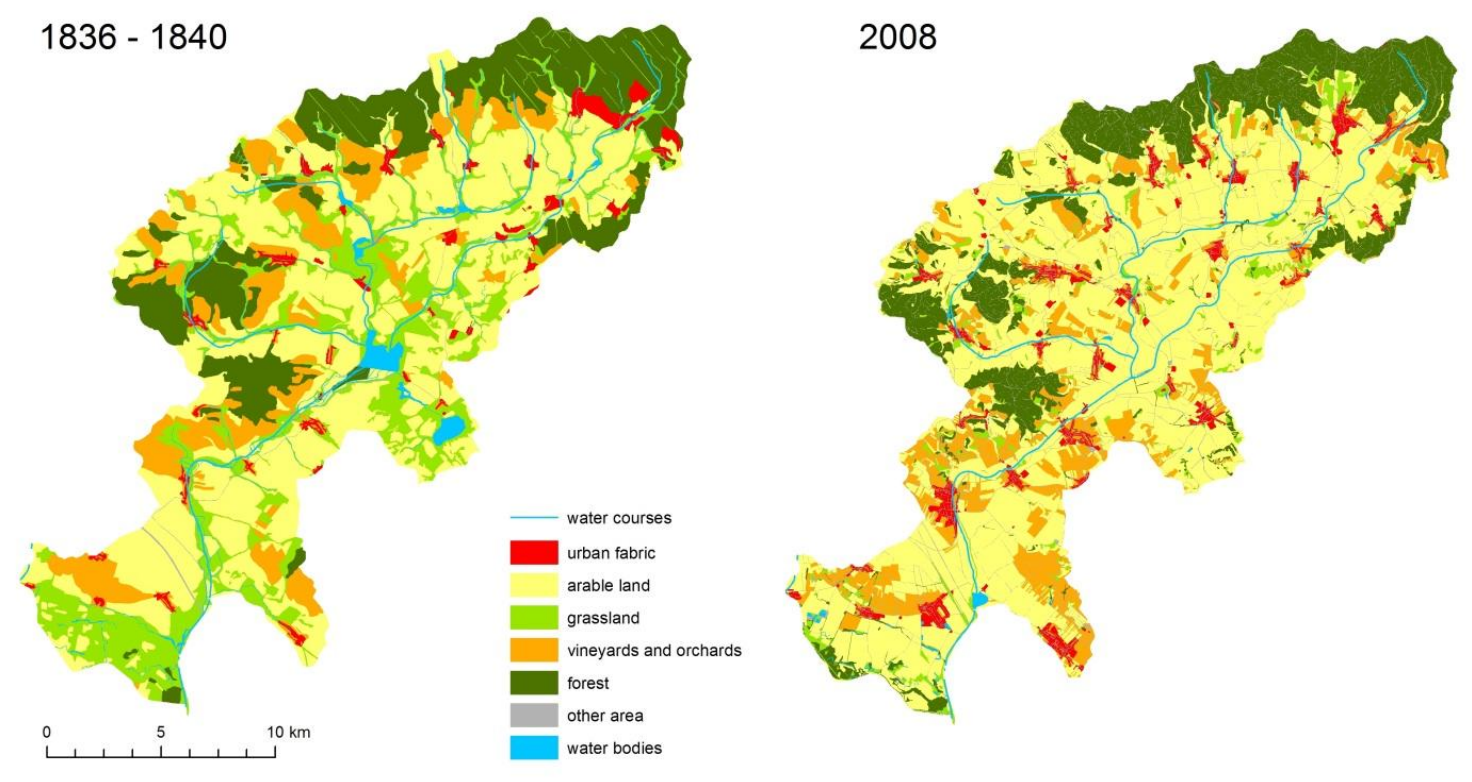

Figure 3. Land-use of the studied area in the years 1836-1840 and 2008 
The 'land cover' category used in the paper is based partially on the CORINE Land Cover classification (Bossard et al., 2000); for the needs of the study it was aggregated into five basic categories and labelled with unique codes: water bodies (1); forest (2); grassland (meadows and pastures) (3); arable land (4), orchards and vineyards (5). These five types, which in combinations create thirteen types of land cover trajectory, were included in the analysis. These trajectories capture land-use change (and include both extensification and intensification processes) and the stability of land use (i.e. the occurrence of categories in both studied periods).

Stable land use:

- Stable forest (22); stable grassland (33); stable arable land (44); stable vineyards and orchards (55)

Changes in land use:

- Forest to grassland (23); forest to arable land (24)

- Grassland to forest (32); grassland to arable land (34)

- Arable land to forest (42); arable land to grassland (43);

- Vineyards and orchards to forest (52); vineyards and orchards to grassland (53); vineyards and orchards to arable land (54)

\section{Biophysical determinants of land use change}

The study analyses selected biophysical variables representing specific limiting or facilitative factors determining land-use changes. Naturally, the link between land-use changes and local natural conditions is not entirely positive. While works such as Chen et al. (2001), Fu et al. (2006) and Pazúr et al. (2014) demonstrated close ties between natural factors and land-use changes, other studies (Schneider and Gil Pontius, 2001; Hietel et al., 2005) suggested only a weak connection between land-use changes and natural conditions. Opršal et al. (2013) confirmed the assumption that environmental factors are more influential in areas with greater topographic heterogeneity. Bajocco et al. (2016) pointed out the important fact that different land-use land-cover change trajectories were associated to different combinations of biophysical factors.

The actual selection of natural factors (Figure 4) was made based on two criteria: i) the possibility of their operationalisation with the use of GIS, and ii) their relevance with respect to representation and variability in the studied area. Firstly, this concerns biophysical factors connected with the topography of the area: slope grade, elevation and aspect (indicating sun exposure). We added also one variable tied to the soil condition fertility. On the other hand, climatic variables were not included in the analysis. Climatic variables (e.g. average temperature, average amount of rainfall) are part of several studies involving vast territories where variability can be anticipated (e.g. Pazúr et al., 2014; Ya et al., 2014, Bajocco et al., 2016). However, as it has been documented (Tolasz et al., 2007) that average annual precipitation and temperature do not show variability in the studied area, the inclusion of these variables was not justified.

Elevation, slope grade and aspect were derived from a digital elevation model (DEM) with a resolution of $1 \mathrm{~m}$. The model was generated from the contour lines which were obtained from the geographic base data of the Czech Republic - ZABAGED ${ }^{\circledR}$. The values of average slope grade, average elevation and aspect were acquired from a digital terrain model in a scale of 1:10,000 using spatial operations in the ArcGIS 10.2 program. Aspect data correspond to azimuth values $0^{\circ}-360^{\circ}$; however, they could not be used in this form in statistical analyses. Orientation data was therefore rescaled into four categories: a slope with 
a predominantly northern exposure $(\mathrm{N})$, a slope with a predominantly eastern exposure $(\mathrm{E})$, a slope with a predominantly southern exposure (S) and slope with a predominantly western exposure (W). After reclassification, aspect data acquired the character of nominal data, and as part of statistical analyses their occurrence or non-occurrence (0/1) was assessed for the given area. In our study we worked on the assumption that higher elevation and higher slope grade variables are associated with extensification processes in land-use change, whereas low elevation and more favourable slope grades have an impact on persistence or intensification of agriculture. As is the case with aspect, with respect to sun exposure extensification processes can also be anticipated in areas with a northern orientation (e.g. the transition of the arable land category to grasslands or grasslands to forest). On the other hand, southern tracts are suitable for agricultural production, and the greater probability of the persistence of the vineyard and orchard category can be expected in the studied area.

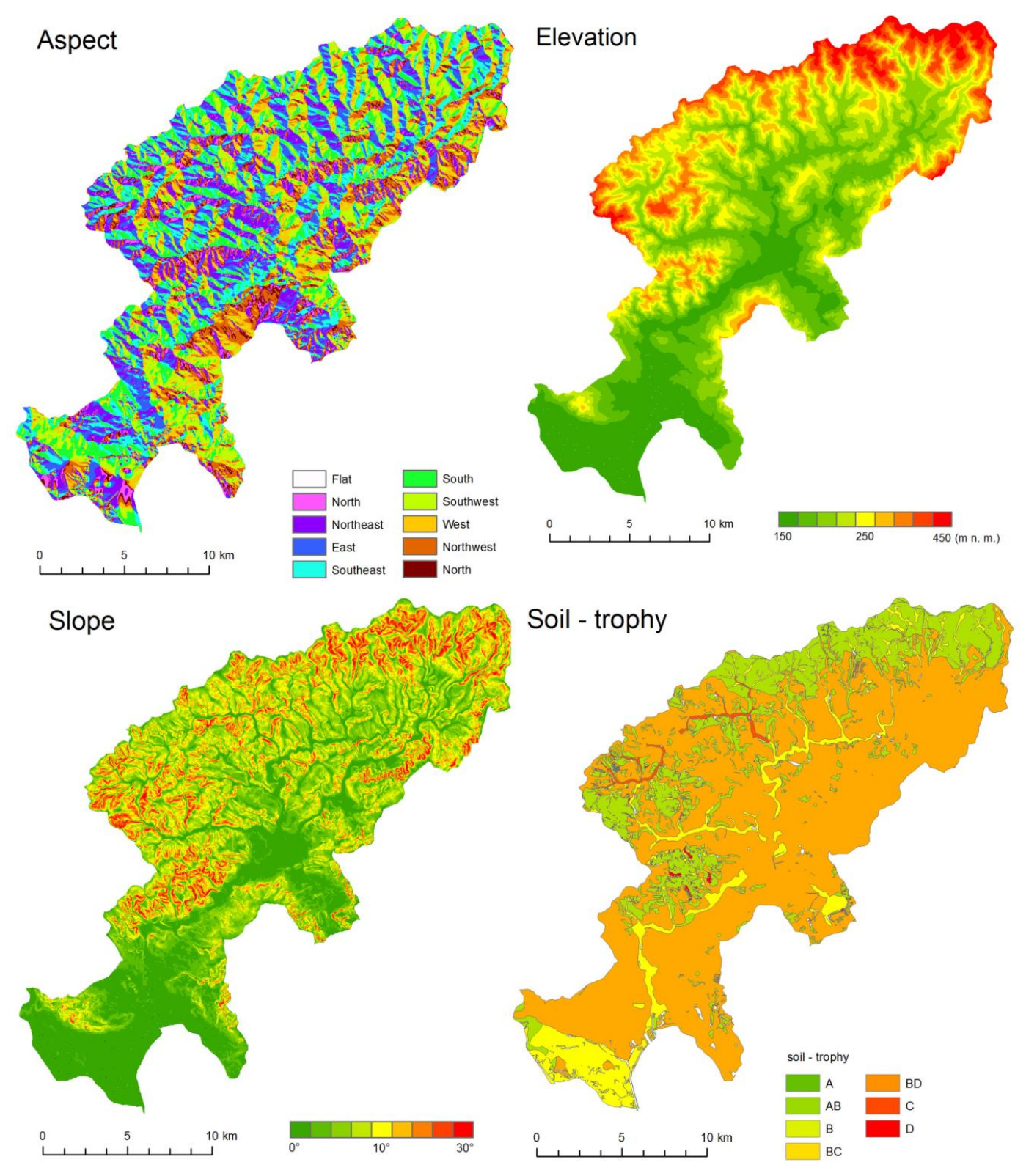

Figure 4. Spatial variation of biophysical factors in the Trkmanka Watershed 
In addition to terrain morphology, soil characteristics represent a significant biophysical constraint to land-use change; nevertheless, a certain lack of uniformity exists in the selection and classification of soil parameters. Used most often are various taxonomic soil categories (see, for instance, Fu et al., 2006; Baumann et al., 2011), the sand/clay ratio in the soil or soil $\mathrm{pH}$ (Prishchepov et al., 2013), and these variables are then associated with soil fertility. Studies by Slovak authors were based on the unique map database of the Bonited Pedo-Ecological Units (Lieskovský et al., 2014; Pazúr et al., 2014), which has also been processed for the Czech Republic. Still, the basic limitation of this map database is the fact that it was created only for agricultural land and not forest land. This means that these resources can only be used for land-use change occurring on agricultural land. However, as our study also includes forest land and other non-agricultural land, an alternative approach was chosen in which the selected parameters of agricultural and forest land were converted to fertility categories using a conversion key (Buček and Lacina, 1999). The transformation of the agricultural land was based on the Main Soil Units, which are expressed in the second and the third position in the five-digit code of the Bonited Pedo-Ecological Units (Novotný et al., 2013). The classification system comprises 78 Main Soil Units (agronomical groupings of similar soil types, subtypes, soil-forming substrates and other characteristic) which were converted into the soil trophy categories (Table 1) derived from the geobiocenological classification system (Buček and Lacina, 1999). Transformation of forest land was based on the map of Forest Types Groups which are a key part of the soil typology used in forestry in the Czech Republic. Forest Types Groups are expressed as three-digit symbols where second symbol indicates edaphic category of the soil (Plíva, 1971). There are 24 edaphic categories of the forestry classification system which can be converted into the above mentioned soil trophy classification based on geobiocenological classification system. The conversion key (Buček and Lacina, 1999) was employed to assign Main Soil Units of agriculture land and edaphic categories of forest land to corresponding soil trophy categories. The result of the process is a common soil classification according to fertility (Table 1). We assumed that extensification processes are associated to a greater degree with less fertile oligotrophic soils.

Table 1. Fertility categories and sub-categories

\begin{tabular}{l|l|l|l}
\hline code & trophy/fertility & code & trophy/fertility \\
\hline A & oligotrophic & AB & oligotrophic-mesophilic \\
B & mesophilic & BC & mesophilic-nitrophilic \\
C & eutrophic-nitrophilic & BD & mesophilic-alkaline \\
D & eutrophic-alkaline & CD & nitrophilic-alkaline \\
\hline
\end{tabular}

In order to establish overall land changes and to determine the relationship between the main transformation processes in the landscape and natural conditions, spatial analyses were conducted by superimposing the digital layers of chosen time horizons. First, the layers representing the transformation of the land cover were created by connecting the digital layers of land use (for the years 1836-1840 and 2008). These newly created layers were then joined with the soil nutrient layer. Spatial operations were used to calculate the values of average slope grade, average elevation and aspect for all of the polygons representing individual types of land development. The results in 
the form of attribute tables served as material for individual statistical analysis of landscape changes and for a canonical correspondence analysis.

The territory as a whole did not enter into the final analyses because only selected types of land-use trajectories (both stable land use and changes in land use) were included. In the process of GIS analysis, the area of $335 \mathrm{~km}^{2}$ was divided into more than 15,000 patches (larger than $1,000 \mathrm{~m}^{2}$ ). Using a simple method of weighted averages (see formula);

$$
\bar{x}=\frac{\sum_{i=1}^{k} x_{i} \cdot n_{i}}{\sum_{i=1}^{k} n_{i}}
$$

where: $x_{i}$ is the value of the given characteristic (e.g. elevation, aspect) of the individual land patch, and $n_{i}$ is the statistical weight of the given land patch, the average characteristics of the studied territory were first established.

The relationship between land-use change (response variables) and selected biophysical characteristics (explanatory variables) was tested using a multidimensional statistical method - canonical correspondence analysis (Lepš and Šmilauer, 2003). All of the more than 15,000 land patches with their characteristics were entered in the CCA (soil fertility, slope grade, elevation, orientation), and each unit was also coded with the type of transformation (or stability). The CCA also included an evaluation of the success of the calculated model, a calculation of the correlation between variables and extracted axes and graphic interpretations. The CCA calculation was conducted using Canoco software for Windows.

\section{Results}

The general characteristics of the analysed variables in the studied territory confirm favourable conditions for agricultural production. The average elevation of the territory is $241 \mathrm{~m}$ above sea level, and the majority of land (42\%) faces south; $29 \%$ of the territory faces east, $26 \%$ faces west and only $3 \%$ has a northern orientation. From the perspective of soil fertility, mesotrophic alkaline dominates with a nearly two-thirds share $(64.4 \%)$, followed by mesotrophic $(22.8 \%)$ and mesophilic-nitrophilic (12\%). The representation of soils from other fertility categories is minor. Due to the favourable values of biophysical factors, it is therefore not surprising that arable soil is dominant with a nearly $70 \%$ share $(68.9 \%)$, followed by forest land $(21.7 \%)$, orchards, gardens and vineyards $(5.3 \%)$; meadows and vineyards currently occupy only $4 \%$ of the territory, despite the fact that at the beginning of the studied period they covered an area nearly five times as large.

An analysis of the relationship between land-use change and selected biophysical conditions using CCA confirmed several assumptions formulated in the introduction. The ordination graph (Figure 5) visualises the relationship of studied variables and land-use transformation. 


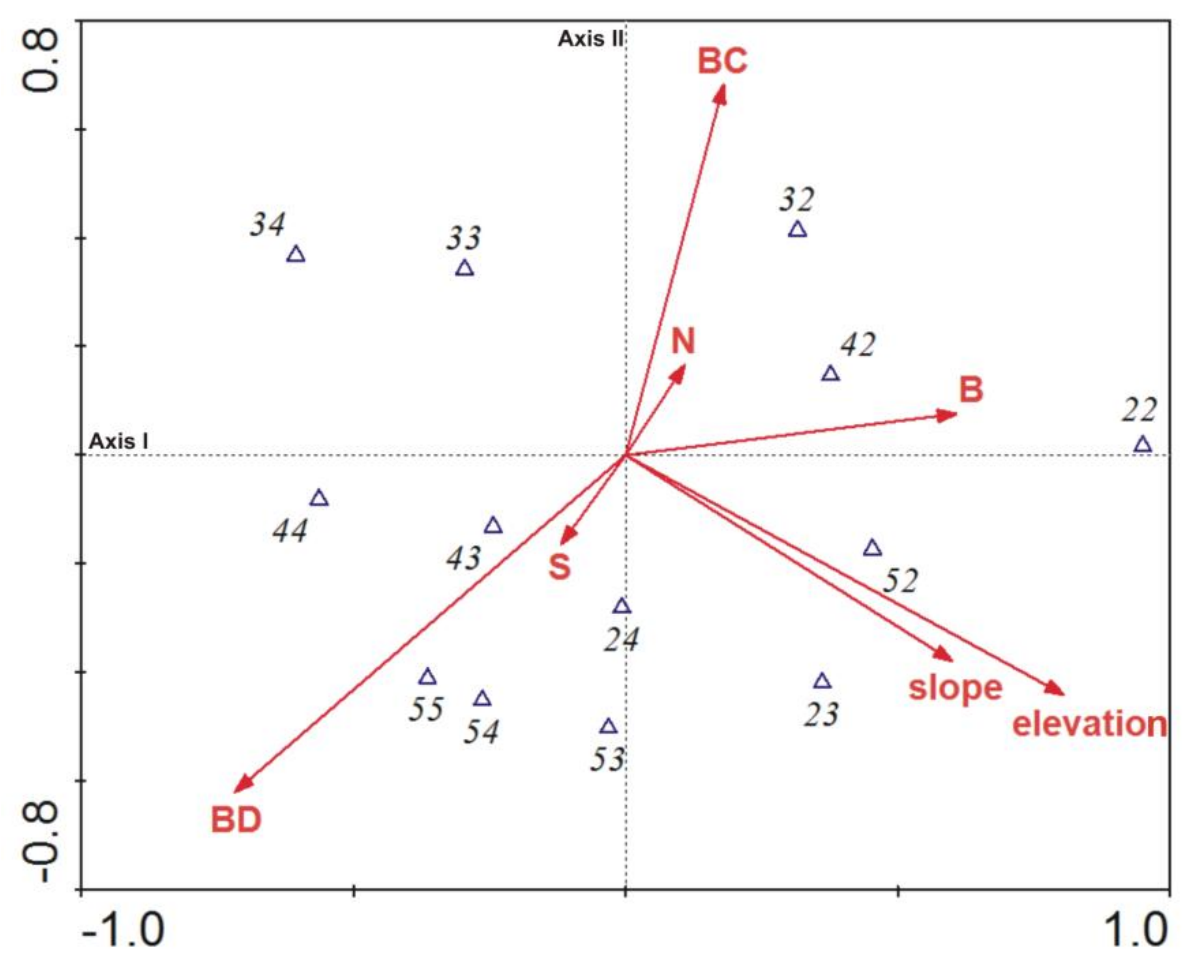

Figure 5. Changes in the use of the landscape and biophysical variables with respect to the first two extracted axes. The length of the arrows determine the correlation between the given variable and the extracted ordination axis; the points represent individual transformation processes. Their location suggests the relationship to individual variables.

Figure 5 shows that the transformations of all types of land-use to forest $(32,42,52)$ are exclusively concentrated on the right side of the graph and positively correlate with the rising slope of the land and increasing elevation. These two variables are positively correlated with the first extracted axis (see Table 2). Also related to these two variables is the stability of forest areas (represented by code 22), which demonstrates the existence of forest stands in both time periods. The mentioned extensification processes are also positively correlated with relatively less fertile (mesotrophic) soils (B). The analysis likewise suggests the role of an unfavourable northern aspect $(\mathrm{N})$, despite the fact that this variable is not statistically conclusive.

In contrast, all intensification processes with ties to a lower slope grade and elevation are found on the left side of the graph. This specifically concerns the $t$ of forest into arable land (24), meadows and pastures into arable land (34) and vineyards and orchards into arable land (54). In addition to intensifaction processes, the mentioned variables are determined by the persistence of intensive forms of land use (i.e. the existence of arable land - code 44, and the existence of vineyards and orchards - code 55, in both periods). Having a significant role in intensification processes from among the variables connected with soil fertility are relatively more fertile mesotrophic alkaline soils (BD). Although aspect is not statistically significant, the accuracy of the analysis is also documented by the direction of the arrows of the south orientation variable $(\mathrm{S})$ toward arable land and vineyards. 
Table 2. Variable entering the analysis and their correlation with extracted axes

\begin{tabular}{lrr}
\hline Variable & Axis 1 & Axis 2 \\
\hline A & 0.0143 & -0.0008 \\
AB & 0.0119 & 0.0220 \\
B & $\mathbf{0 . 4 4 5 7}$ & 0.0241 \\
BC & 0.1324 & $\mathbf{0 . 2 1 6 6}$ \\
BD & $\mathbf{- 0 . 5 2 7 2}$ & -0.1968 \\
C & -0.0473 & 0.0431 \\
D & 0.1142 & 0.0079 \\
Elevation & $\mathbf{0 . 5 9 0 9}$ & -0.1401 \\
Slope & $\mathbf{0 . 4 4 0 6}$ & -0.1203 \\
N & 0.0794 & 0.0525 \\
S & -0.0871 & -0.0522 \\
E & 0.0477 & 0.0079 \\
W & -0.0018 & 0.0163 \\
\hline
\end{tabular}

The advantage of CCA is the possibility of establishing the statistical success of the entire model (Hietel et al., 2005; Opršal et al., 2013), which other geostatistical methods do not enable (Bakker et al., 2011; Druga and Falt’an, 2014; Pazúr et al., 2014). At first glance, the statistical success of the model is not high (only $7 \%$ of the original information is explained by the model), a situation caused by several factors. The first is the number of units used in the CCA, the second the intensity of land-use changes in the Trkmanka Watershed. Nearly a third of the overall territory underwent transformation during the studied period. These factors impacted the analysis, and the authors encountered a similar problem at other heavily transformed sites (Opršal et al., 2013).

Despite the limited reliability of the model, the relationship between land-use changes and biophysical variables was confirmed to a certain degree using multidimensional statistics. Evidence of this is provided in Figure 6, which captures the land units that always underwent the relevant transformation; ovals designate the part of the graph in which their dominant share occurs. Their position with respect to the extracted axes again indicates a link to the environmental variables whose vectors are depicted in Figure 5.

a)

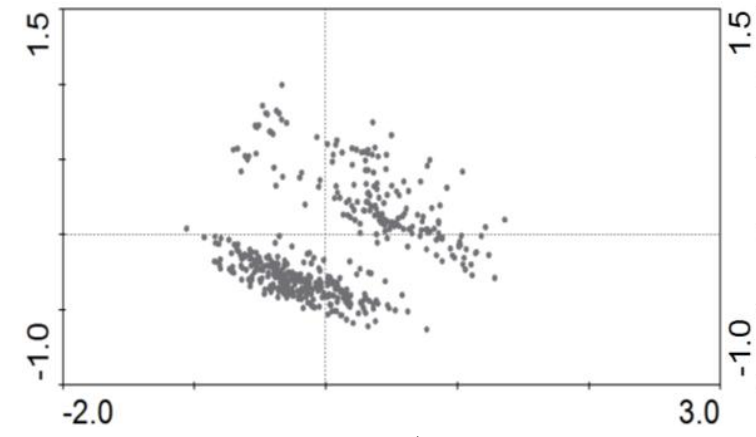

c) b)

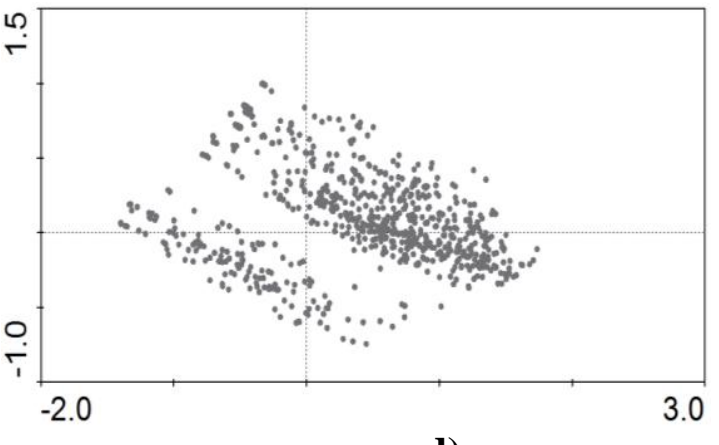

d) 


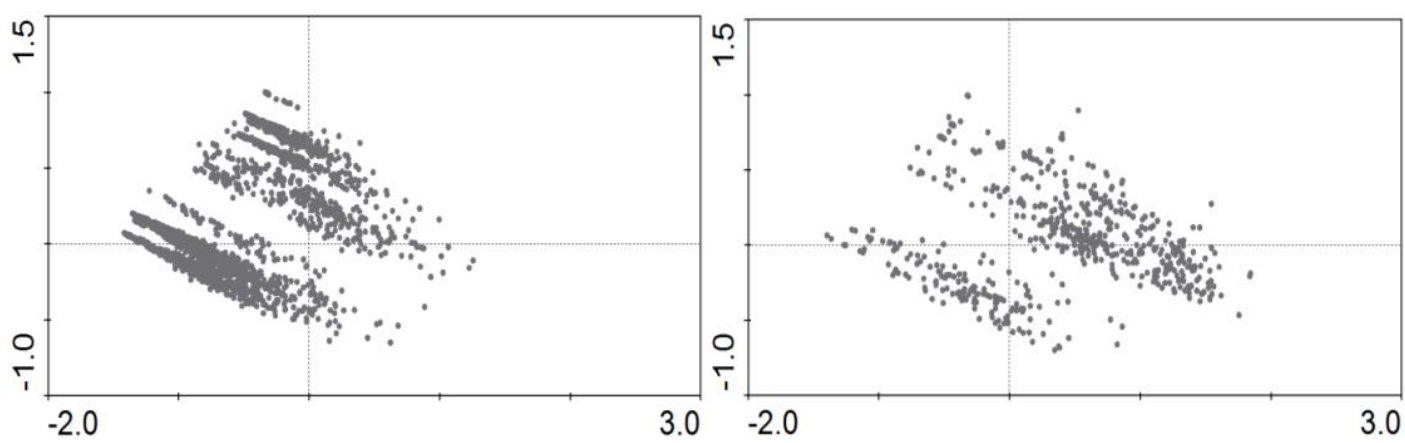

Figure 6. Individual CCA results - the location of units of the selected land-use transformation in relation to the first two extracted axes (Axis I-horizontal; Axis II-vertical). Key: transformation type: a) forest to arable land (24); b) grassland to forest (32); c) grassland to arable land (34); d) arable land to forest (42).

\section{Discussion}

In our analysis we were able to confirm the significance of all included variables in the land-use transformation process. We found slope grade and elevation to be extremely significant in extensification processes and land abandonment, which is consistent with the conclusions of studies from other regions ( $\mathrm{Fu}$ et al., 2006; Kuemmerle et al., 2008; Müller et al., 2013; Liu et al., 2010; Druga and Falt'an, 2014). These topographical factors seem to be dominant, and their influence is less significant in only a few cases (Pazúr et al., 2014). Moreover, slope grade and elevation can also influence other biophysical factors such as soil quality and socioeconomic factors, particularly isolation, land accessibility and the ability to use modern mechanisation to cultivate parcels. Therefore, we can designate less favourable topographic conditions as key predictive factors for extensification and land abandonment not only in agriculturally marginal (mountainous) areas but also on those with a tradition of intensive agricultural production. In contrast, favourable slope grade and elevation characteristics are associated with the intensification of agricultural production (the transition of grassland to arable land in the case of the Trkmanka Watershed).

Another significant biophysical characteristic is soil fertility, which has an influence on both extensification processes (on land with relatively low fertility) and intensification processes (on relatively fertile land). The significance of soil fertility must therefore be tied to a specific type of land-use change; for example, a great significance was confirmed in the transition of vineyards and orchards to forests, while a surprisingly low significance was found in the transition of arable land to grassland. This is possible to explain in the studied territory of the Trkmana Watershed by the fact that a large part of meadows and pastures were located on flat alluvial land that was converted to arable land after it was drained. Relatively high significance of soil fertility also appears in other studies (Szillasi et al., 2010; Baumann et al., 2011; Prishchepov et al., 2013a; Pazúr et al., 2014), while others state only small or average significance (Hietel et al., 2004; Alvarez Martinez et al., 2011). However, an evaluation and especially the direct comparison of the influence of soil factors is complicated by the lack of uniformity in the selection and classification of soil parameters (cf. Fu et al., 2006; Prishchepov et al., 2013; Baumann et al., 2011).

The final investigated variable was aspect. This factor is often omitted from studies (e.g. Müller and Munroe, 2008; Liu et al., 2010; Lieskovský et al., 2014), which is 
clearly related to methodological difficulties in geostatistical analyses. Although the orientation of the slope toward one of the four cardinal directions proved to be statistically insignificant in our study, the ordination diagram (Figure 5) suggests an association between slopes with a southern exposure and intensive land-use forms. On the other hand, northern exposures suggest the greater probability of transition from arable land or grassland to forest. It is logical in this context that vineyards and orchards show the highest degree of stability on slopes with a southern exposure.

Our study demonstrated the significance of selected biophysical factors on land-use change over the long-term. Nevertheless, we are aware that our chosen approach has several methodological limits, e.g. in the selection of maps, the precision of the cartographic materials from the Second Military Mapping Survey and their conversion to digital form. We believe that the relatively large territory contributed to the sufficiently robust results supporting the aforementioned analysis results. It should also be emphasised that land-use changes are a dynamic process that cannot be reduced to a single set of factors (Munroe et al., 2013; Vliet et al., 2015; Geist and McConell, 2010; Bajocco et al., 2016). The conclusions of many studies point to the importance of socioeconomic factors, some of which such as relative accessibility and isolation of areas (Olah et al., 2006; Baumann et al., 2011; Lieskovský et al., 2014) or depopulation (Renwick et al., 2013; Pazúr et al., 2014) can be modelled in broader land-use studies. It is clear that additional influences related to the economic and political context of the evaluated period and territory also play a role. For instance, Havlíček et al. (2014) identified unprofitable fish breeding, the development of sugar beet industry and higher demand for food and technical crops as main driving forces responsible for the disappearance of water bodies in the Trkmanka watershed. It can be expected that other factors such as land ownership, systems of agricultural support and the individual decisions of farmers based on personal values and motivations may affect the land-use changes. The mentioned factors cannot be included in simple deterministic models and require different approaches based on questionnaires at sites with the greatest intensity of changes (Hersperger et al., 2010). Moreover, despite the significance of socioeconomic drivers land use of an area, its changes and distribution remains affected by the local natural conditions (Olah et al., 2006). Finally, the decision not to incorporate socioeconomic factors is also related to the chosen timeframe; for a period of more than 150 years it is possible to consider biophysical factors as essentially stable, whereas the explanatory potential of socioeconomic factors can be very limited. Nevertheless, as our research has shown, even an analysis of actual biophysical factors can reveal hotspots of potential changes and become a useful tool for predicting landscape development (Pechanec and Machar, 2014) and sustainable landscape management (Machar, 2013).

\section{Conclusion}

This article evaluates the impact of selected biophysical factors on land-use changes using the example of the Trkmanka Watershed in the southeast part of the Czech Republic. It is one of a small number of studies focused on the territory, which has a predominance of intensive agricultural production. Utilising unique historical cartographic documents, the study assesses the influence of biophysical factors over a time period of more than 150 years. The results of a canonical correspondence analysis (CCA) demonstrated the correlation between selected variables and land-use changes. 
The most significant variables were slope grade, elevation and soil fertility; aspect was of limited importance.

Our study showed that while extensification processes are minor on heavily farmed land compared to marginal mountainous or arid areas (Pazúr et al., 2014; Lasanta and Vicente-Serrano, 2012), they are still conditioned on less favourable environmental circumstances. The extensification of farming is especially related to a higher slope grade and elevation, while the analyses also suggest the influence of an unfavourable northern aspect and less fertile soil. Likewise, less favourable natural factors condition the persistence of extensive forms of land use (especially the likelihood of the continued existence of forest stands). In contrast, the stability of intensive forms of agricultural production or further intensification are associated with a lower slope grade and elevation, more fertile soils, and a more favourable southern exposure also plays a role.

Although the results of the statistical analyses confirmed the importance of natural factors, they explain only some of the overall land-use changes. While it is clear that socioeconomic factors are the main forces influencing the character of land use (Vliet et al., 2015), their inclusion in the CCA is significantly limited due to their nature and variability. Environmental and socioeconomic factors do not act separately but produce a mutual interaction (Geist and McConell, 2010). Nevertheless, independent analyses of natural factors are justified, since they help anticipate land-use changes in the long-term and identify hotspots of change. The results can be used to predict land-use changes and for strategic land-use planning and sustainable land management.

\section{REFERENCES}

[1] Alvarez Martinez, J.M., Suarez-Seoane, S., De Luis Calabuig, E. (2011): Modelling the risk of land cover change from environmental and socio-economic drivers in heterogeneous and changing landscapes: The role of uncertainty. - Landscape and Urban Planning 101: 108-119.

[2] Antrop, M. (2005): Why landscapes of the past are important for the future. - Landscape and Urban Planning 70(1-2): 21-34.

[3] Bakker, M.M., Hatna, E., Kuhlman, T., Mücher, C. (2011): Changing environmental characteristics of European cropland. - Agricultural Systems 104(7): 522-532.

[4] Baumann, M., Kuemmerle, T., Elbakidze, M., Ozdogan, M., Radeloff, V.C., Keuler, N.S.,. Prishchepov, A.V, Kruhlov, I., Hostert, P. (2011): Patterns and drivers of postsocialist farmland abandonment in Western Ukraine. - Land Use Policy 28(3): 552-562.

[5] Bičík, I., Jeleček, L., Štěpánek, V. (2001): Land-use changes and their social driving forces in Czechia in the 19th and 20th centuries. - Land Use Policy 18(1): 65-73.

[6] Boguszak, F., Šlitr, J. (1962): Topografie. - SNTL, Praha.

[7] Bossard, M., Feranec, J., Ot'ahel', J. (2000): CORINE land cover technical guide Addendum 2000, Copenhagen.

[8] Buček, A., Lacina, J. (1999): Geobiocenologie II. - Mendelova zemědělská a lesnická universita, Brno.

[9] Cousins, S.A.O. (2001): Analysis of land-cover transitions based on 17th and 18th century cadastral maps and aerial photographs. - Landscape Ecology 16(1): 41-54.

[10] Demek, J., Mackovčin, P. (2006): Zeměpisný lexikon ČR. Hory a nížiny vydání II. Agentura ochrany prírody a krajiny ČR, Praha.

[11] Demek, J. and Novák, V., (1992): Vlastivěda moravská. Neživá příroda. - Muzejní a vlastivědná společnost, Brno. 
[12] Druga, M., Falt'an, V. (2014): Influences of Environmental Drivers on Land Cover Structure and its Long-Term Changes: a Case Study of the Villages of Malachov and Podkonice in Slovakia. - Moravian Geographical Reports 22(3): 29-41.

[13] Duraiappah, A.K., Naeem, S., (2005): Millennium Ecosystem Assessment, 2005. Ecosystems and Human Well-being: Biodiversity Synthesis.

[14] Feng, X., Wang, Y., Chen, L., Fu, B., Bai, G. (2010): Modeling soil erosion and its response to land-use change in hilly catchments of the Chinese Loess Plateau. Geomorphology 118(3-4): 239-248.

[15] Fu, B.J., Zhang, Q.J., Chen, L.D., Zhao, W.W., Gulinck, H., Liu, G.B., Yang, Q.K., Zhu, Y.G. (2006): Temporal change in land use and its relationship to slope degree and soil type in a small catchment on the Loess Plateau of China. - Catena 65(1): 41-48.

[16] Geist, H., McConell, W. (2010): Causes and Trajectories of Land-Use/Cover Change. In F. E. Lambin and H. Geist, eds. Land-Use and Land-Cover Change. Local Processes and Global Impacts, Springer, Berlin.

[17] Gerard, F., Petit, S., Smith, G., Thomson, A., Brown, N., Manchester, S., Wadsworth, R., Bugar, G., Halada, L., Bezàk, P., Boltiziar, M., De badts, E., Halabuk, A., Mojses, M., Petrovic, F., Gregor, M., Hazeu, G., Mücher, C.A., Wachowicz, M., Huitu, H., Tuominen, S., Köhler, R., Olschofsky, K., Ziese, H., Kolar, J., Sustera, J., Luque, S., Pino, J., Pons, X., Roda, F., Roscher, M., Feranec, J. (2010): Land cover change in Europe between 1950 and 2000 determined employing aerial photography. - Progress in Physical Geography 34(2): 183-205.

[18] Havlíček, M., Pavelková, R., Frajer, J., Skokanová, H. (2014): The long-term development of water bodies in the context of land use: The case of the Kyjovka and Trkmanka River Basins (Czech Republic). - Moravian Geographical Reports 22(4): 3950 .

[19] Hersperger, A.M., Gennaio, M.P., Verburg, P.H., Bürgi, M. (2010): Linking land change with driving forces and actors: Four conceptual models. - Ecology and Society, 15.

[20] Hietel, E., Waldhardt, R, Otte, A. (2004): Analysing land-cover changes in relation to environmental variables in Hesse, Germany. - Landscape Ecology, 19(5): 473-489.

[21] Hietel, E., Waldhardt, R., Otte, A. (2005): Linking socio-economic factors, environment and land cover in the German Highlands, 1945-1999. - Journal of environmental management 75(2): 133-143.

[22] Hietel, E., Waldhardt, R., Otte, A. (2007): Statistical modeling of land-cover changes based on key socio-economic indicators. - Ecological Economics 62(3-4): 496-507.

[23] Chen, L., Wang, J., Fu, B., Qiu, Y. (2001): Land-use change in a small catchment of northern Loess Plateau, China. Agriculture, - Ecosystems and Environment 86: 163-172.

[24] Kanianska, R., Kizeková, M., Nováček, J., Zeman, M. (2014): Land-use and land-cover changes in rural areas during different political systems: A case study of Slovakia from 1782 to 2006. - Land Use Policy 36: 554-566.

[25] Kiliánová, H., Pechanec, V., Lacina, J., Halas, P. (2009): Ekotony v současné krajině. Analýza a modelování ekotonů v povodí Trkmanky 1. vydání. - Univerzita Palackého v Olomouci, Olomouc.

[26] Krausmann, F., Haberl, H., Schulz, N.B., Erb, K.H., Darge, E., Gaube, V. (2003): Landuse change and socio-economic metabolism in Austria - Part I: Driving forces of land-use change: 1950-1995. - Land Use Policy 20(1): 1-20.

[27] Kuemmerle, T., Hostert, P., Radeloff, V.C., van der Linden, S., Perzanowski, K., Kruhlov, I. (2008): Cross-border comparison of post-socialist farmland abandonment in the Carpathians. - Ecosystems 11(4): 614-628.

[28] Kuemmerle, T., Müller, D., Griffiths, P., Rusu, M. (2009): Land use change in Southern Romania after the collapse of socialism. - Regional Environmental Change 9(1): 1-12.

[29] Lambin, E.F., Turner, B.L., Geist, H.J., Agbola, S.B., Angelsen, A., Bruce, J.W., Coomes, O.T., Dirzo, R., Fischer, G., Folke, C., George, P.S., Homewood, K., Imbernon, J., Leemans, R., Li, X., Moran, E.F., Mortimore, M., Ramakrishnan, P.S., Richards, J.F., 
Skånes, H., Steffen, W., Stone, G.D., Svedin, U., Veldkamp, T.A., Vogel, C., Xu, J. (2001): The causes of land-use and land-cover change: moving beyond the myths. Global Environmnetal Change 11: 261-269.

[30] Lasanta, T., Vicente-Serrano, S.M. (2012): Complex land cover change processes in semiarid Mediterranean regions: An approach using Landsat images in northeast Spain. Remote Sensing of Environment 124: 1-14.

[31] Lepš, J., Šmilauer, P. (2003): Multivariate Analysis of Ecological Data using CANOCO. - Cambridge University Press, New York.

[32] Li, X., Xiao, D., He. X., Chen, W., Song, D. (2007): Factors associated with farmland area changes in arid regions: A case study of the Shiyang River basin, northwestern China. - Frontiers in Ecology and the Environment 5: 139-144.

[33] Li, Z., Liu, W., Zhang, X., Zheng, F., (2009): Impacts of land use change and climate variability on hydrology in an agricultural catchment on the Loess Plateau of China. Journal of Hydrology 377: 35-42.

[34] Lieskovský, J., Kenderessy, P., Špulerová, J., Lieskovský, T., Koleda, P., Kienast, F., Gimmi, U. (2014): Factors affecting the persistence of traditional agricultural landscapes in Slovakia during the collectivization of agriculture. - Landscape Ecology 29(5): 867877.

[35] Lisec, A. and Navratil, G. (2013): Avstrijski zemljiški kataster: od prvih začetkov do sodobnega zemljiškega informacijskega sistema. Austrian land cadastre: from the earliest beginnings to the modern land information system. - Geodetski vestnik 58(3): 482-516.

[36] Liu, J., Zhang, Z, Xu, X., Kuang, W., Zhou, W., Zhang, S., Li, R., Yan, C., Yu, D., Wu, S., Jiang, N. (2010): Spatial patterns and driving forces of land use change in China during the early 21st century. - Journal of Geographical Sciences 20 (4): 483-494.

[37] Łowicki, D. (2008): Land use changes in Poland during transformation. - Landscape and Urban Planning 87(4): 279-288.

[38] Machar, I. (2013): Applying landscape ecological principles in sustainable forest management of the floodplain forest in the temperate zone of Europe. - Ekológia (Bratislava) 32(4): 369-375.

[39] Mitsuda, Y., Ito, S. (2011): A review of spatial-explicit factors determining spatial distribution of land use/land-use change. - Landscape and Ecological Engineering 7(1): $117-125$.

[40] Müller, D., Kuemmerle, T., Rusu, M., Griffiths, P. (2009): Lost in transition: determinants of post-socialist cropland abandonment in Romania. - Journal of Land Use Science 4(1-2): 109-129.

[41] Müller, D., Leitão, P.J., Sikor, T. (2013): Comparing the determinants of cropland abandonment in Albania and Romania using boosted regression trees. - Agricultural Systems 117: 66-77.

[42] Müller, D., Munroe, D.K. (2008): Changing Rural Landscapes in Albania: Cropland Abandonment and Forest Clearing in the Postsocialist Transition. - Annals of the Association of American Geographers 98(4): 855-876.

[43] Munroe, D.K., van Berkel, D.B., Verburg P.H., Olson J.L. (2013): Alternative trajectories of land abandonment: Causes, consequences and research challenges. - Current Opinion in Environmental Sustainability 5(5): 471-476.

[44] Novotný, I., Vopravil, J., Kohoutová, L., Poruba, M., Papaj, V., Khel, T., Žigmund, I., Vašků, Z., Tomiška, Z., Koutná, R., Pacola, M., Novotný, J., Havelková, L., Brouček, J., Žížala, D. (2013): Metodika mapování a aktualizace bonitovaných půdně ekologických jednotek. 4., přepr. a dopl. vyd. - Výzkumný ústav meliorací a ochrany půdy, Praha.

[45] Olah, B., Boltižiar, M., Petrovič, F. (2006) Land use changes' relation to georelief and distance in the East Carpathians biosphere reserve - Ekológia 25(1): 68-81.

[46] Opršal, Z., Šarapatka, B., Kladivo, P. (2013): Land-use changes and their relationships to selected landscape parameters in three cadastral areas in Moravia (Czech Republic). Moravian Geographical Reports 21(1): 41-50. 
[47] Pazúr, R., Lieskovský, J., Feranec, J., Ot’ahel', J. (2014): Spatial determinants of abandonment of large-scale arable lands and managed grasslands in Slovakia during the periods of post-socialist transition and European Union accession. - Applied Geography 54: $118-128$.

[48] Pechanec, V. and Machar, I. (2014): Implementation of decision support tools in ArcGIS and IDRISI and their environmental applications. - International Journal of Circuits, Systems and Signal Processing 8: 388-398.

[49] Pereira, H.M., Leadley, P.W., Proença, V., et al., (2010): Scenarios for global biodiversity in the 21st century. - Science, 330: 1496-1501.

[50] Petit, C.C., Lambin, E.F. (2002): Long-term land-cover changes in the Belgian Ardennes (1775-1929): Model-based reconstruction vs. historical maps. - Global Change Biology 8: 616-630.

[51] Prishchepov, A.A., Müller, D., Dubinin, M., Baumann, M., Radeloff, V.C. (2013): Determinants of agricultural land abandonment in post-Soviet European Russia. - Land Use Policy 30(1): 873-884.

[52] Plíva, K. (1971): Typologický systém ÚHUL. - Ústav pro hospodářskou úpravu lesů, Brandýs nad Labem

[53] Renwick, A., Jansson, T., Verburg, P.H, Revoredo-Gihaa, C., Britzd, W., Gochte, W., McCrackena, D. (2013): Policy reform and agricultural land abandonment in the EU. Land Use Policy 30(1): 446-457.

[54] Schneeberger, N., Bürgi, M., Hersperger, A.M., Ewald, K.C. (2007): Driving forces and rates of landscape change as a promising combination for landscape change research - An application on the northern fringe of the Swiss Alps. - Land Use Policy 24(2): 349-361.

[55] Schneider, L.C., Gil Pontius, R. (2001): Modeling land-use change in the Ipswich watershed, Massachusetts, USA. - Agriculture, Ecosystems and Environment 85: 83-94.

[56] Serra, P., Pons, X., Saurí, D. (2008): Land-cover and land-use change in a Mediterranean landscape: a spatial analysis of driving forces integrating biophysical and human factors. - Applied Geography 28: 189-209.

[57] Song, W., Chen, B. and Zhang, Y. (2013): Land-use change and socio-economic driving forces of rural settlement in China from 1996 to 2005. - Chinese Geographical Science 24(5): $1-14$.

[58] Stone, B. (2009): Land use as climate change mitigation. Environmental science and technology 43: 9052-9056.

[59] Szilassi, P., Jordan, G., Kovacs, F., Rompaey, A.V., Dessel, W.V. (2010): Investigating the link between soil quality and agricultural land use change. A case study in the Lake Balaton Catchment, Hungary. - Carpathian Journal of Earth and Environmental Sciences 5(2): 61-70.

[60] Timár, G., Molnár, G. (2013): Map grids and datums. Eötvös Lóránd University, Budapest.

[61] Tolasz, R. (2007): Atlas podnebí Česka. Climate atlas of Czechia - Český hydrometeorologický ústav, Universita Palackého, Praha, Olomouc.

[62] Turner II, B.L. (1997): The Sustainability Principle in Global Agendas: Implications for Understanding Land-Use/Cover Change. - The Geographical Journal 163: 133-140.

[63] Veldkamp, A., Lambin, E. (2001): Predicting land-use change. - Agriculture, Ecosystems and Environment 85(1-3): 1-6.

[64] Verburg, P.H, Ritsema van Eck J.R, de Nijs, T.C.M, Dijst, M.J., Schot, P. (2004): Determinants of land-use change patterns in the Netherlands. - Environment and Planning B: Planning and Design 31(1): 125-150.

[65] Verburg, P.H., van de Steeg, J., Veldkamp, A., Willemen, L. (2009): From land cover change to land function dynamics: a major challenge to improve land characterization. Journal of Environmental Management 90: 1327-1335. 
[66] Verburg, P.H., Overmars, K.P. (2009): Combining top-down and bottom-up dynamics in land use modeling: Exploring the future of abandoned farmlands in Europe with the Dyna-CLUE model. - Landscape Ecology 24(9): 1167-1181.

[67] Vitousek, P.M., Mooney, H., Lubchenco, J., Melillo, J.M. (1997): Human Domination of Earth's Ecosystems. - Science 277: 494-499.

[68] Vliet, J. Van, Groot, H.L.F. De, Rietveld, P., Verburg, P.H. et al., (2015): Manifestations and underlying drivers of agricultural land use change in Europe. - Landscape and Urban Planning 133: 24-36.

[69] Xu, J., Ma, E.T., Tashi, D., Fu, Y., Lu, Z., Melick, D. (2005): Integrating sacred knowledge for conservation: Cultures and landscapes in Southwest China. - Ecology and Society 10.

[70] Zhang, Q.J. Fu, B.J., Chen, L.D., Zhao, W.W., Yang, Q.K., Liu, G.B., Gulinck, H. (2004): Dynamics and driving factors of agricultural landscape in the semiarid hilly area of the Loess Plateau, China. - Agriculture, Ecosystems and Environment 103: 535-543.

[71] Zorn, M., Komac, B., (2009): Response of soil erosion to land use change with particular reference to the last 200 years (Julian Alps, Western Slovenia). - Revista de geomorfologie 11: 39-47.

\section{ELECTRONIC APPENDIX}

Electronic appendix 1: Input matrix of the RDA analysis 